\title{
PENGAWASAN PASAR MODAL SETELAH BERLAKUNYA UNDANG- UNDANG NOMOR 21 TAHUN 2011 TENTANG OTORITAS JASA KEUANGAN
}

\author{
Suwardi \\ (Universitas Muhammadiyah Kotabumi) \\ suwardi.amri@gmail.com
}

\begin{abstract}
Abtract: The capital market is seen as an effective means to accelerate the development of a country because of its ability to mobilize long-term funds from the public to be channeled to productive sectors. However, trading traffic on the capital market requires supervision from the government or parties that are considered to be independent to create safe and comfortable market conditions for each party that will carry out the transaction. This article raises the issue of how to control the capital market before and after the enactment of the Law Number 21 of 2011 concerning the Financial Services Authority ?. The writing of this article uses a normative approach in analyzing various laws and regulations as well as literature related to capital market developments. The process of data analysis is done qualitatively. The function of the capital market supervision after the enactment of Law Number 21 of 2011 concerning OJK replaces the function previously performed by the Capital Market Supervisory Agency (Bapepam). Supervision under the OJK is based on a passion to give attention to protection and education for consumers. Education and protection of financial consumers is directed to increase the trust of investors and consumers in every activity and business activity in the financial services sector and provide opportunities and opportunities for the development of the financial services sector in a fair, efficient and transparent manner.
\end{abstract}

Keywords: capital market, supervision

\begin{abstract}
Abstak : Pasar modal dipandang sebagai salah satu sarana yang efektif untuk mempercepat pembangunan suatu negara karena kemampuannya menggalang pengerahan dana jangka panjang dari masyarakat untuk disalurkan ke sektor-sektor produktif. Meski demikian lalu lintas perdagangan di pasar modal memerlukan pengawasan dari pihak pemerintah atau pihak yang dianggap independen untuk menciptakan kondisi pasar yang aman dan nyaman bagi setiap pihak yang akan melakukan transaksi.Artikel ini mengajukan permasalahan bagaimanakah pengawasan pasar modal sebelum dan setelah berlakunya Undang-Undang Nomor 21 Tahun 2011 Tentang Otoritas Jasa Keuangan?.Penulisan artikel ini menggunakan pendekatan normatif dalam menganalisis berbagai peraturan perundang-undangan serta literatur yang terkait dengan perkembangan pasar modal. Proses analisis data dilakukan secara kualitatif.Fungsi pengawasan pasar modal setelah berlakunya Undang-Undang Nomor 21 Tahun 2011 Tentang OJK mengantikan fungsi yang sebelumnya dilakukan oleh Badan Pengawas Pasar Modal (Bapepam).Pengawasan di bawah OJK dilandasi semangat untuk memberikan perhatian kepada perlindungan dan edukasi bagi konsumen.Edukasi dan perlindungan konsumen keuangan diarahkan untuk meningkatkan kepercayaan dari investor dan konsumen
\end{abstract}

LEGALITA, Vol. 01, No. 01 Agustus-Desember 2019 | 63 
dalam setiap aktivitas dan kegiatan usaha di sektor jasa keuangan serta memberikan peluang dan kesempatan untuk perkembangan sektor jasa keuangan secara adil, efisien, dan transparan.

\section{Kata kunci : pasar modal, pengawasan}

\section{A. Pendahuluan}

Pasar modal dipandang sebagai salah satu sarana yang efektif untuk mempercepat pembangunan suatu negara. Hal ini dimungkinkan karena pasar modal merupakan wahana yang dapat menggalang pengerahan dana jangka panjang dari masyarakat untuk disalurkan ke sektor-sektor produktif. Apabila pengerahan dana masyarakat melalui lembaga keuangan maupun pasar modal sudah dapat berjalan dengan baik, maka dana pembangunan yang bersumber dari luar negeri makin lama makin dikurangi. ${ }^{1}$

Seperti halnya pasar pada umumnya, pasar modal merupakan tempat bertemunya antara penjual dan pembeli namun yang membuat keduanya berbeda adalah objek yang diperjualbelikan. Di pasar modal yang dperjualbelikan adalah hak atas kepemilikan suatu perusahaan dalam bentuk saham dan dan pernyataan utang perusahaan yang disebut dengan obligasi. Pada dasarnya fungsi pasar modal sebagai wahana demokratisasi pemilikan saham yang ditunjukkan dengan semakin banyaknya perusahaan dan perseorangan yang memiliki saham perusahaan yang telah ditawarkan kepada masyarakat umum (go public). Pasar modal adalah salah satu sumber pembiayaan perusahaan secaa jangka panjang. Keberadaan institusi ini bukan hanya sebagai wahana sumber pembiayaan saja, tetapi juga sebagai sarana bagi masyarakat untuk mendapatkan kesempatan memperoleh dan meningkatkan kesejahteraan. ${ }^{2}$

Lalu lintas perdagangan di pasar modal memerlukan pengawasan dari pihak pemerintah atau pihak yang dianggap independen untuk menciptakan kondisi pasar yang aman dan nyaman bagi setiap pihak yang akan melakukan transaksi. Di

1Pandji Anoraga dan Piji Pakarti, Pengantar Pasar Modal (Jakarta: Cipta Rineka 2008). hlm. 1

${ }^{2}$ M. Irsan Nasarudin dkk, Aspek Hukum Pasar Modal Indonesia, (Jakarta: Kencana Prenada Media Group, 2011). hlm. 27

LEGALITA, Vol. 01, No. 01 Agustus-Desember 2019 | 64 
dalam Pasal 3 ayat (1) Undang-Undang Nomor 8 Tahun 1995 tentang Pasar Modal dinyatakan bahwa pembinaan, pengaturan dan pengawasan sehari-hari kegiatan Pasar Modal dilakukan oleh Badan Pengawas Pasar Modal yang selanjutnya disebut Bapepam. Kemudian di dalam Pasal 4 Undang-Undang tersebut dinyatakan bahwa Pembinaan, pengaturan, dan pengawasan sebagaimana dimaksud dalam Pasal 3 dilaksanakan oleh Bapepam dengan tujuan mewujudkan terciptanya kegiatan Pasar Modal yang teratur, wajar, dan efisien serta melindungi kepentingan pemodal dan masyarakat.

Perkembangan selanjutnya, pemerintah menerbitkan Undang-Undang Nomo 21 Tahun 2011 tentang Otoritas Jasa Keuangan yang pemberlakuannya dimulai pada 31 Desember 2012. Salah satu tugas Otoritas Jasa Keuangan (OJK) adalah menggantikan fungsi pengawasan dan pembinaan terhadap pasar modal yang selama ini dilakukan oleh Bapepam. Berbeda dengan Bapepam yang keberadaannya berada di bawah Kementerian Keuangan, OJK adalah lembaga yang independen dan bebas dari campur tangan pihak lain, yang mempunyai fungsi, tugas, dan wewenang pengaturan, pengawasan, pemeriksaan, dan penyidikan.OJK berfungsi menyelenggarakan sistem pengaturan dan pengawasan yang terintegrasi terhadap keseluruhan kegiatan di dalam sektor jasa keuangan. OJK didirikan untuk menggantikan peran Bapepam dalam pengaturan dan pengawasan pasar modal dan lembaga keuangan, serta menggantikan peran Bank Indonesia dalam pengaturan dan pengawasan bank, serta untuk melindungi konsumen industri jasa keuangan.

\section{B. Permasalahan}

Permasalahan yang diangkat dalam artikel ini adalah bagaimanakah pengawasan pasar modal sebelum dan setelah berlakunya Undang-Undang Nomor 21 Tahun 2011 Tentang Otoritas Jasa Keuangan?

LEGALITA, Vol. 01, No. 01 Agustus-Desember 2019 |65 


\section{Metode}

Penulisan artikel ini menggunakan pendekatan normatif dalam menganalisis berbagai peraturan perundang-undangan serta literatur yang terkait dengan perkembangan pasar modal. Proses analisis data dilakukan secara kualitatif.

\section{Pembahasan}

Secara historis, pasar modal sebenarnya telah hadir jauh sebelum Indonesia merdeka.Pasar modal atau bursa efek telah hadir sejak jaman kolonial Belanda dan tepatnya pada tahun 1912 di Batavia. Pasar modal ketika itu didirikan oleh pemerintah Hindia Belanda untuk kepentingan pemerintah kolonial atau VOC.Meskipun pasar modal telah ada sejak tahun 1912, perkembangan dan pertumbuhan pasar modal tidak berjalan seperti yang diharapkan, bahkan pada beberapa periode kegiatan pasar modal mengalami kevakuman. Hal tersebut disebabkan oleh beberapa faktor seperti perang dunia ke I dan II, perpindahan kekuasaan dari pemerintah kolonial kepada pemerintah Republik Indonesia, dan berbagai kondisi yang menyebabkan operasi bursa efek tidak dapat berjalan sebagimana mestinya.

Pemerintah Republik Indonesia mengaktifkan kembali pasar modal melalui penerbitanUndang-Undang Nomor 8 Tahun 1995 tentang Pasar Modal dan beberapa tahun kemudian pasar modal mengalami pertumbuhan seiring dengan berbagai insentif dan regulasi yang dikeluarkan pemerintah.Pasal 1 angka 13 UU Nomor 8 Tahun 1995 tentang Pasar Modal mendefiniskan bahwa Pasar Modal adalah kegiatan yang bersangkutan dengan Penawaran Umum dan perdagangan Efek, Perusahaan Publik yang berkaitan dengan Efek yang diterbitkannya, serta lembaga dan profesi yang berkaitan dengan Efek.

Secara singkat, fase-fase perkembangan pasar modal di Indonesia dapat dilihat sebagai berikut:

LEGALITA, Vol. 01, No. 01 Agustus-Desember 2019 | 66 
Tabel 1 Perkembangan Pasar Modal di Indonesia ${ }^{3}$

\begin{tabular}{|c|c|}
\hline Tanggal/Tahun & Kegiatan \\
\hline 02 Maret 2009 & $\begin{array}{l}\text { Peluncuran Oerdana Sistem Perdagangan Baru PT Bursa Efek } \\
\text { Indonesia: JATS-NextG }\end{array}$ \\
\hline 2007 & $\begin{array}{l}\text { Penggabungan Bursa Efek Surabaya (BES) ke Bursa Efek } \\
\text { Jakarta (BEJ) dan berubah nama menjadi Bursa Efek Indonesia } \\
\text { (BEI }\end{array}$ \\
\hline 2002 & $\begin{array}{l}\text { BEJ mulai mengaplikasikan sistem perdagangan jarak jauh } \\
\text { (remote trading) }\end{array}$ \\
\hline 2000 & $\begin{array}{l}\text { Sistem Perdagangan Tanpa Warkat (scripless trading) mulai } \\
\text { diaplikasikan di pasar modal Indonesia }\end{array}$ \\
\hline 1995 & Bursa Paralel Indonesia merger dengan Bursa Efek Surabaya \\
\hline $\begin{array}{ll}10 & \text { NOVEMBER } \\
1995 & \end{array}$ & $\begin{array}{l}\text { Pemerintah mengeluarkan Undang -Undang No. } 8 \text { Tahun } \\
1995 \text { tentang Pasar Modal. Undang-Undang ini mulai } \\
\text { diberlakukan mulai Januari } 1996\end{array}$ \\
\hline 22 MEI 1995 & $\begin{array}{l}\text { Sistem Otomasi perdagangan di BEJ dilaksanakan dengan } \\
\text { sistem computer JATS (Jakarta Automated Trading Systems) }\end{array}$ \\
\hline 13 JULI 1992 & $\begin{array}{l}\text { Swastanisasi BEJ. BAPEPAM berubah menjadi Badan } \\
\text { Pengawas Pasar Modal. Tanggal ini diperingati sebagai HUT } \\
\text { BEJ }\end{array}$ \\
\hline 16 JUNI 1989 & $\begin{array}{l}\text { Bursa Efek Surabaya (BES) mulai beroperasi dan dikelola oleh } \\
\text { Perseroan Terbatas milik swasta yaitu PT Bursa Efek Surabaya }\end{array}$ \\
\hline DESEMBER 1988 & $\begin{array}{l}\text { Pemerintah mengeluarkan Paket Desember } 88 \text { (PAKDES 88) } \\
\text { yang memberikan kemudahan perusahaan untuk go public } \\
\text { dan beberapa kebijakan lain yang positif bagi pertumbuhan } \\
\text { pasar modal }\end{array}$ \\
\hline 2 JUNI 1988 & Bursa Paralel Indonesia (BPI) mulai beroperasi dan dikelola \\
\hline
\end{tabular}

3Sejarah dan Milestone, diakses dari www.idx.co.id/tentang-bei/sejarah-danmilestone/, pada tanggal 31 Mei 2019 pukul 10.47

LEGALITA, Vol. 01, No. 01 Agustus-Desember 2019 | 67 


\begin{tabular}{|c|c|}
\hline & $\begin{array}{l}\text { oleh Persatuan Perdagangan Uang dan Efek (PPUE), } \\
\text { sedangkan organisasinya terdiri dari broker dan dealer }\end{array}$ \\
\hline $1988-1990$ & $\begin{array}{l}\text { Paket deregulasi dibidang Perbankan dan Pasar Modal } \\
\text { diluncurkan. Pintu BEJ terbuka untuk asing. Aktivitas bursa } \\
\text { terlihat meningkat }\end{array}$ \\
\hline 1987 & $\begin{array}{l}\text { Ditandai dengan hadirnya Paket Desember } 1987 \text { (PAKDES 87) } \\
\text { yang memberikan kemudahan bagi perusahaan untuk } \\
\text { melakukan Penawaran Umum dan investor asing } \\
\text { menanamkan modal di Indonesia }\end{array}$ \\
\hline $1977-1987$ & $\begin{array}{l}\text { Perdagangan di Bursa Efek sangat lesu. Jumlah emiten hingga } \\
1987 \text { baru mencapai 24. Masyarakat lebih memilih instrumen } \\
\text { perbankan dibandingkan instrumen Pasar Modal }\end{array}$ \\
\hline 10 AGUSTUS 1977 & $\begin{array}{l}\text { Bursa Efek diresmikan kembali oleh Presiden Soeharto. BEJ } \\
\text { dijalankan dibawah BAPEPAM (Badan Pelaksana Pasar } \\
\text { Modal). Pengaktifan kembali pasar modal ini juga ditandai } \\
\text { dengan go public PT Semen Cibinong sebagai emiten pertama }\end{array}$ \\
\hline $1956-1977$ & Perdagangan di Bursa Efek vakum \\
\hline 1956 & $\begin{array}{l}\text { Program nasionalisasi perusahaan Belanda. Bursa Efek } \\
\text { semakin tidak aktif }\end{array}$ \\
\hline $1942-1952$ & Bursa Efek di Jakarta ditutup kembali selama Perang Dunia II \\
\hline AWAL 1939 & $\begin{array}{l}\text { Karena isu politik (Perang Dunia II) Bursa Efek di Semarang } \\
\text { dan Surabaya ditutup }\end{array}$ \\
\hline $1925-1942$ & $\begin{array}{l}\text { Bursa Efek di Jakarta dibuka kembali bersama dengan Bursa } \\
\text { Efek di Semarang dan Surabaya }\end{array}$ \\
\hline $1914-1918$ & Bursa Efek di Batavia ditutup selama Perang Dunia I \\
\hline DESEMBER 1912 & $\begin{array}{l}\text { Bursa Efek pertama di Indonesia dibentuk di Batavia oleh } \\
\text { Pemerintah Hindia Belanda }\end{array}$ \\
\hline
\end{tabular}

LEGALITA, Vol. 01, No. 01 Agustus-Desember 2019 |68 
Sebelum berlakunya Undang-Undang Nomor 21 Tahun 2011 tentang Otoritas Jasa Keuangan, pengawasan terhadap kegiatan pasar modal dilakukan oleh Badan Pengawas Pasar Modal (Bapepam). Bapepam-LK adalah sebuah lembaga di bawah Kementerian Keuangan Indonesia yang bertugas membina, mengatur, dan mengawasi sehari-hari kegiatan pasar modal serta merumuskan dan melaksanakan kebijakan dan standardisasi teknis di bidang lembaga keuangan. Bapepam-LK merupakan penggabungan dari Badan Pengawas Pasar Modal (Bapepam) dan Direktorat Jenderal Lembaga Keuangan.

Bapepam merupakan lembaga pemerintah yang bertugas untuk melakukan pembinaan, pengaturan, dan pengawasan sehari-hari terhadap pasar modal bila terjadi pelanggaran-pelanggaran dalam bursa efek. Peran Bapepam sebagai (Badan Pengawas Pasar Modal) mengatur untuk melakukan pembinaan dan pengaturan dan pengawasan sehari-hari pasar modal dengan tujuan mewujudkan tujan dan terciptanya kegiatan pasar yang efisien, dan serta melindungi kepentingan masyarakat pemodal. ${ }^{4}$

Bapepam berada dibawah dan bertanggung jawab kepada Menteri ada tujuan selain pengawas juga Bapepam bertujuan agar untuk mencegah kerugian, di dalam masyarakat sebagai akibat dari pelanggaran atas ketentuan di bidang pasar modal, baik itu dalam Saham, Obligasi, Waran, Opsi, Reksadana, dan saham-saham lain yang ada di pasar modal.Adanya Bapepam sebagai badan pengawas dimaksudkan agar tidak terjadi suatu pelanggaran seperti penipuan, manipulasi pasar, dan perdagangan orang dalam, atau terjadinya penggelapan. Sehingga adanya kepastian hukum dan perlindungan hukum terhadap investor menyimpan sarana investasi atau menanamkan investasi di pasar modal aman. Pada dasarnya UUPM telah meletakkan landasan bagi penegakkan hukum untuk setiap pelanggaran terhadap kegiatan pasar modal yakni:

1. Sanksi adminsitratif (pasal 102 UUPM)

2. Sanksi Pidana (Pasal 103 UUPM)

${ }^{4}$ Rusdin, Pasar Modal (Bandung: Alfabeta, 2005). hlm. 10

LEGALITA, Vol. 01, No. 01 Agustus-Desember 2019 |69 


\section{Tuntutan ganti rugi secara perdata (Pasal 111 UUPM $)^{5}$}

Undang-Undang Nomor 8 Tahun 1995 tentang Pasar Modal mengatur mengenai pelanggaran di pasar modal. Kejahatan di pasar modal dapat dibagi menjadi dua yaitu delik pelanggaran dan delik tindak pidana di bidang pasar modal. Pelanggaran terhadap peraturan perundang-undangan di pasar modal merupakan pelanggaran yang sering dilakukan oleh pihak-pihak yang terlibat di dalam kegiatan pasar modal.Pelanggaran di pasar modal merupakan pelanggaran yang sifatnya teknis administratif.Pelanggaran yang bersipat administrasi ialah pelanggaran yang berkaitan dengan laporan atau dokumen kepada BAPEPAM dan atau masayarakat (pasal 25-pasal 89 UUPM). Laporan tersebut baik berkala maupun aporan yang isensial yang berisikan fakta material yang sangat penting dan relevan mengenai atau peristiwa yang ada bisa mengakibatkan berpengaruhnya harga, atau segala bentuk informasi maupun fakta yang dapat mempengaruhi pihak investor atau pihak lain yang ada hubungannya dengan pasar modal. Sedangkan pelanggaran yang bersifat teknis ialah pelanggaran ini yaitu segala kegiatan yang menyangkut segala bentuk perizinan, persetujuan dan pendaftaran ke BAPEPAM.

Delik tindak pidana di bidang pasar modal ialah kejahatan yang dilakukan oleh pihak-pihak dalam kegiatan pasar modal yaitu dalam melakukan kegiatan perdagangan efek yang terjadi dalam rangka penawaran umum, atau di bursa efek atau di luar bursa atas efek emiten atau perusahaan publik, baik secara langsung maupun tidak langsung melakukan perbuatan atau tindakan seperti penipuan, transaksi dua atau lebih efek, manipulasi pasar dan insider trading sebagaimana telah diatur dalam UU Nomor 8 Tahun 1995.Adanya sanksi yang akan diberikan Bapepam bila pelanggaran dilakukan oleh emiten atau selaku orang dalam di pasar modal sesuai dengan Pasal 95 Undang-Undang Pasar Modal yang dimaksud disini orang dalam yaitu:

1. Komisaris, Direktur, atau Pegawai emiten atau perusahaan Publik

2. Pemegang saham utama emiten atau perusahaan Publik

${ }^{5}$ Lastuti Abubakar, Taransaksi Derifatif Di Indonesia (Bandung: Books terrace\& Library, 2009). hlm. 316.

LEGALITA, Vol. 01, No. 01 Agustus-Desember 2019 |70 
3. Orang perseorangan yang karena kedudukan atau profesinya atau karena hubungan usahanya dengan emiten atau perusahaan Publik memungkinkan orang tersebut memperoleh informasi orang dalam. ${ }^{6}$

Tindakan Bapepam muncul apabila terjadi suatu pelanggaran dilakukan oleh orang dalam maka Bapepam mempunyai hak untuk mengadakan pemeriksaan terhadap setiap pihak yang diduga telah terlibat melakukan suatu pelanggaran sebelumnya juga Bapepam akan meminta keterangan terhadap emiten atau orang yang terlibat dalam pelanggaran juga memerintahkan kepada pihak yang diduga untuk tidak melakukan kegiatan di pasar modal.

Jika benar-benar pelanggaran itu terjadi dan membahayakan kepentingan pemodal dan masyarakat maka, maka Bapepam dapat menetapkan untuk dimulainya tindakan penyidikan. Adanya penyidikan dilakukan PPNS (Penyidik Pegawai Negeri Sipil) penyidikan disini melakukan pemeriksaan, keterangan barang bukti kepada pihak yang telah di sangka dan melakukan pemeriksaan setiap tempat yang diduga terdapat dokumen-dokumen, serta melakukan penyitaan terhadap barang yang didapat, juga memblokir pada bank atau lembaga keuangan dari pihak yang diduga melakukan tindak Perdata (ganti kerugian) atau sanksi Pidana (yaitu hukuman penjara). ${ }^{7}$

Apabila terjadi delik tindak pidana di pasar modal, maka Bapepam dapat mengadakan pemeriksaan dan penyidikan terhadap setiap pihak yang diduga telah, atau melakukan atau terlibat dalam pelanggaran terhadap UUPM dan atau peraturan pelaksanaannya.Apa bila terjadi pelanggaran administrasi dapatkan dikenakan Pasal 102 Ayat (2) UUPM berupa adanya peringatan tertulis, denda yaitu kewajiban untuk membayar sejumlah uang tertentu, dan pembatasan kegiatan

6Undang-Undang No. 8 Tahun 1995 Tentang Pasar Modal

${ }^{7}$ Yusuf anwar, Penegakan Hukum dan Pengawasan Pasar Modal Indonesia (Bandung: Alumni, 2008). hlm.111-112 
usaha juga pencanbutan izan usaha dan dan pembatalan persetujuan dan pembatalan pendaftaran. ${ }^{8}$

Mengenai saksi pidana diatur dalam Pasal 103 UUPM sampai dengan Pasal 110 UUPM, yang jenis pidananya dapat berupa pidana penjara, pidana kurungan atau denda. Sanksi pidana diberikan kepada pelaku pasar modal yang telah melakukan delik tindak pidana pasar modal antara lain penipuan, manipulasi pasar, dan perdagangan orang dalam.Sesuai dengan aspek hukum pengawasan didalam pasar modal apepam Pasal 1 ayat 3 Undang-Undang Pasar Modal disini Bapepam mempunyai hak yang luas, yakni sebagai pembina dan pengawas dan seharirí-hari didalam pasar modal agar tidak terjadi hal-hal yang merugikan investor dan tidak ada lagi pelanggaran yang dilakukan emiten.

Pada perkembangannya lahir Undang-undang Nomor 21 Tahun 2011 Tentang Otoritas Jasa Keuangan (OJK). Peran Bapepam digantikan oleh lembaga bernama Otoritas Jasa Keuangan (OJK) yang Undang-undang Nomor 21 Tahun 2011 yang berfungsi menyelenggarakan sistem pengaturan dan pengawasan yang terintegrasi terhadap keseluruhan kegiatan di dalam sektor jasa keuangan baik di sektor perbankan, pasar modal, dan sektor jasa keuangan non-bank seperti Asuransi, Dana Pensiun, Lembaga Pembiayaan, dan Lembaga Jasa Keuangan lainnyaPasal 1 ayat (4) UU Nomor 21 Tahun 2011 Tentang OJK menjelaskan bahwa, lembaga-lembaga yang akan berada di bawah pengawasan OJK adalah perbankan, pasar modal, perasuransian, dana pensiun, lembaga pembiayaan atau multifinance, dan lembaga jasa keuangan lainnya.

Lembaga jasa keuangan ini mencakup pergadaian (PT Pegadaian), lembaga penjaminan, lembaga pembiayaan ekspor Indonesia, lembaga pembiayaan sekunder perumahan dan lembaga yang menyelenggarakan pengelolaan dana masyarakat yang bersifat wajib, yaitu penyelenggaraan program jaminan sosial, pensiun, dan kesejahteraan.OJK adalah lembaga yang independen dan bebas dari campur tangan pihak lain, yang mempunyai fungsi, tugas, dan wewenang pengaturan,

${ }^{8}$ Artawan, Peranan Pasar Modal di Masa Mendatang (JakartaP: PT BEJ, 2002). hlm. 31 
pengawasan, pemeriksaan, dan penyidikan. OJK dibentuk berdasarkan UU Nomor 21 Tahun 2011 yang berfungsi menyelenggarakan sistem pengaturan dan pengawasan yang terintegrasi terhadap keseluruhan kegiatan di dalam sektor jasa keuangan.OJK didirikan untuk menggantikan peran Bapepam-LK dalam pengaturan dan pengawasan pasar modal dan lembaga keuangan, serta menggantikan peran Bank Indonesia dalam pengaturan dan pengawasan bank, serta untuk melindungi konsumen industri jasa keuangan.Tugas pengawasan industri keuangan non-bank dan pasar modal secara resmi beralih dari Kementerian Keuangan dan Bapepam-LK ke OJK pada 31 Desember 2012.Sedangkan pengawasan di sektor perbankan beralih ke OJK pada 31 Desember 2013 dan Lembaga Keuangan Mikro pada 2015.9

Pasal 4 UU Nomor 21 Tahun 2011 tentang OJK menyebutkan bahwa OJK dibentuk dengan tujuan agar keseluruhan kegiatan di dalam sektor jasa keuangan terselenggara secara teratur, adil, transparan, akuntabel dan mampu mewujudkan sistem keuangan yang tumbuh secara berkelanjutan dan stabil, serta mampu melindungi kepentingan konsumen maupun masyarakat.Melalui pembentukan OJK, maka lembaga ini diharapkan dapat mendukung kepentingan sektor jasa keuangan secara menyeluruh sehingga meningkatkan daya saing perekonomian.Selain itu, OJK harus mampu menjaga kepentingan nasional. Antara lain meliputi sumber daya manusia, pengelolaan, pengendalian, dan kepemilikan di sektor jasa keuangan dengan tetap mempertimbangkan aspek positif globalisasi. OJK dibentuk dan dilandasi dengan prinsip-prinsip tata kelola yang baik, yang meliputi independensi, akuntabilitas, pertanggungjawaban, transparansi, dan kewajaran (fairness).

OJK mulai berfungsi menyelenggarakan sistem pengaturan dan pengawasan yang terintegrasi terhadap keseluruhan kegiatan di dalam sektor jasa

${ }^{9}$ FAQ Otoritas Jasa Keuangan, diakses dari, https://www.ojk.go.id/id/Pages/FAQOtoritas-Jasa-Keuangan.aspx, pada tanggal 23 Mei 2019 pukul 10.47

LEGALITA, Vol. 01, No. 01 Agustus-Desember 2019 |73 
keuangan.Berdasarkan Pasal 6 dari UU No 21 Tahun 2011, tugas utama dari OJK adalah melakukan pengaturan dan pengawasan terhadap:

a. Kegiatan jasa keuangan di sektor Perbankan;

b. Kegiatan jasa keuangan di sektor Pasar Modal;

c. Kegiatan jasa keuangan di sektor Perasuransian, Dana Pensiun, Lembaga Pembiayaan, dan Lembaga Jasa Keuangan Lainnya.

Terkait pasar modal, kejahatan pasar modal memiliki suatu keunikan sendiri dibandingkan kejahatan kejahatan yang ada didalam dunia kriminal biasa, hal ini dikarenakan modus serta tindakan kejahatannya mempunyai karakteristik yang sudah diatur didalam Undang Undang Pasar Modal.Didalam UU No.8 Tahun 1995 mengenai Pasar Modal jenis kejahatan terdiri dari :

1. Penipuan (Fraud), hal ini tertuang dalam Pasal 90 UUPM.

2. Manipulasi Pasar, tertuang didalam Pasal 91 dan Pasal 92 UUPM.

3. Insider Trading ( Perdagangan Orang Dalam) hal ini tertuang didalam Pasal 95 s/d Pasal 99

4. Informasi Menyesatkan (Missleading Information), tertuang dalam Pasal 80; Pasal 81; serta Pasal 93 UUPM.

Jika terjadi Tindakan Kejahatan tersebut diatas, maka Otoritas Jasa Keuangan berhak untuk melakukan proses pemeriksaan dan penyidikan terhadap Pihak Pihak yang melakukan jenis tindak kejahatan tersebut. Adapun cara menangani kejahatan didalam Pasar Modal memiliki alur yang sangat kompleks yang terdiri dari beberapa tahap yaitu :

1. Pemeriksaan yang dilakukan oleh OJK dengan membentuk PNS Penyidik tertentu didalam OJK.

2. Pelaporan, dalam hal ini pemeriksa akan melakukan pemeriksaan dan melakukan pelaporan atas hasil pemeriksaan tersebut kepada Bagian Eksekutif Pasar Modal dan akan dilanjutkan kepada Dewan Komisioner OJK.

3. Penyidikan, apabila hasil pemeriksaan ditemukan suatu bukti adanya tindak pidana didalam Pasar Modal. 
4. Pemberian sanksi oleh OJK kepada para pelanggar bisa berupa peringatan tertulis,denda,pembekuan izin kegiatan usaha,pencabutan izin usaha,pembatalan persetujuan dan pembatalan pendaftaran.

5. Dan jika hal tersebut diatas dan memang terjadi tindak pidana maka akan dilanjutkan kepada Jaksa Penuntut Umum.

Perbedaan Pengawasan yang ada sebelumnya dengan Pengawasan di Bawah OJK Pengawasan di bawah OJK dilandasi semangat untuk memberikan perhatian kepada perlindungan dan edukasi bagi konsumen.Edukasi dan perlindungan konsumen keuangan diarahkan untuk mencapai dua tujuan utama.Pertama, meningkatkan kepercayaan dari investor dan konsumen dalam setiap aktivitas dan kegiatan usaha di sektor jasa keuangan. Kedua, memberikan peluang dan kesempatan untuk perkembangan sektor jasa keuangan secara adil, efisien, dan transparansi. Dalam jangka panjang, industri keuangan sendiri juga akan mendapat manfaat yang positif untuk memacu peningkatan efisiensi sebagai respon dari tuntutan pelayanan yang lebih prima terhadap pelayanan jasa keuangan. Adapun pihak-pihak yang diawasi oleh OJK dalam hal sektor Pasar modal ini adalah:

1. Emiten dan Perusahaan Publik

Emiten adalah Pihak yang melakukan Penawaran Umum, sedangkan Penawaran Umum adalah kegiatan penawaran Efek yang dilakukan oleh Emiten untuk menjualEfek kepada masyarakat dan Efek adalah Efek adalah surat berharga, yaitu surat pengakuan utang, surat berharga komersial , saham, obligasi, tanda bukti utang, Unit Penyertaan kontrak investasi kolektif, kontrak berjangka atas Efek, dan setiap derivatif dari Efek. Perusahaan publik atau Perusahaan terbuka adalah perusahaan yang sebagian atau seluruh sahamnya dimiliki oleh masyarakat. Penjualan saham ke masyarakat dilakukan dengan cara Initial Public Offering (IPO). OJK mengawasi data mengenai seluruh Emiten dan Perusahaan Publik yang telah mendapatkan Pernyataan Efektif dari Bapepam dan ditampilkan dari Sistem Database Emiten dan Perusahaan Publik (CoreSystem) yang dikembangkan oleh Bapepam-LK.

LEGALITA, Vol. 01, No. 01 Agustus-Desember 2019 |75 


\section{Reksa Dana}

Reksa Dana adalah wadah yang dipergunakan untuk menghimpun dana dari masyarakat pemodal untuk selanjutnya diinvestasikan dalam Portofolio Efek oleh Manajer Investasi. OJK mengawasi beberapa Agen Penjual Efek Reksa Dana Yang Sudah Terdaftar di Bapepam-LK. Data aktivitas dan pengelolaan Reksa Dana ditampilkan dalam Sistem Pusat Informasi Reksa Dana. Melalui sistem ini, akan diperoleh gambaran aktivitas Reksa Dana secara keseluruhan (industri) maupun individual.

\section{Wakil Perusahaan Efek}

Wakil Perusahaan Efek adalah pihak perwakilan Perusahaan Efek yang melakukan kegiatan usaha sebagai Penjamin Emisi Efek, Perantara Pedagang Efek, dan atau Manajer Investasi. OJK mengawasi berdasarkan Database Wakil Perusahaan Efek yang telah mendapatkan izin orang perseorangan sebagai Wakil Perusahaan Efek. Izin orang perseorangan bagi Wakil Perusahaan Efek meliputi izin sebagai Wakil Perantara Pedagang Efek (PPE), Wakil Penjamin Emisi Efek (PEE), dan Wakil Manajer Investasi (MI).

4. Profesi Penunjang

Profesi Penunjang adalah profesi pemberian jasa mengenai pendapat atau penilaian yang diberikan oleh Profesi Penunjang Pasar Modal yang dilakukan secara

profesional dan bebas dari pengaruh Pihak yang memberikan tugas dan menggunakan jasa Profesi Penunjang Pasar Modal tersebut dan atau afiliasinya sehingga pendapat atau penilaian yang diberikan objektif dan wajar.

5. Lembaga Penunjang Pasar Modal

Lembaga Penunjang Pasar Modal terdiri dari:

a. Kustodian, adalah Pihak yang memberikan jasa penitipan Efek dan harta lain yang berkaitan dengan Efek serta jasa lain, termasuk menerima dividen, bunga, dan hak - hak lain, menyelesaikan transaksi Efek, dan mewakili pemegang rekening yang menjadi nasabahnya.

b. Wali amanat, adalah Pihak yang mewakili kepentingan pemegang Efek yang bersifat utang. Wali Amanat mewakili kepentingan pemegang Efek bersifat 
utang atau sukuk baik di dalam maupun di luar pengadilan. Dalam hal ini Wali Amanat diberi kuasa berdasarkan Undang-Undang ini untuk mewakili pemegang efek bersifat utang atau sukukdalam melakukan tindakan hukum yang berkaitan dengan kepentingan pemegang efek bersifat utang atau sukuk tersebut, termasuk melakukan penuntutan hak-hak pemegang efek bersifat utang atau sukuk baik di dalam maupun di luar pengadilan tanpa memerlukan surat kuasa khusus dari pemegang efek bersifat utang atau sukuk dimaksud.

c. Biro Administrasi Efek, adalah Pihak yang berdasarkan kontrak dengan Emiten melaksanakan pencatatan pemilikan Efek dan pembagian hak yang berkaitan dengan Efek.

d. Perusahaan Pemeringkat Efek, adalah Penasihat Investasi berbentuk Perseroan Terbatas yang melakukan kegiatan pemeringkatan dan memberikan peringkat. Dalam melaksanakan kegiatannya, Perusahaan Pemeringkat Efek wajib terlebih dahulu mendapatkan izin usaha dari Bapepam dan LK. Perusahaan Pemeringkat Efek wajib melakukan kegiatan pemeringkatan secara independen, bebas dari pengaruh pihak yang memanfaatkan jasa Perusahaan Pemeringkat Efek, obyektif, dan dapat dipertanggungjawabkan dalam pemberian Peringkat. Perusahaan Pemeringkat Efek dapat melakukan

Melalui fungsi dan kontrol serta penindakan yang lebih tegas serta didukung oleh adanya peraturan perundang- undangan yang lebih khusus Otoritas Jasa Keuangan diharapkan akan mampu sebagai Leader didalam Pemberantasan Tindak Pidana Kejahatan didalam Pasar Modal dan dapat memberikan Perlindungan Hukum terhadap Seluruh Investor di Negara Republik Indonesia.

\section{E. Kesimpulan}

Krisis ekonomi 1997-1998 yang dialami Indonesia mengharuskan pemerintah melakukan pembenahan di sektor perbankan dalam rangka melakukan stabilisasi 
sistem keuangan dan mencegah terulangnya krisis.Fungsi pengawasan pasar modal setelah berlakunya Undang-Undang Nomor 21 Tahun 2011 Tentang Otoritas Jasa Keuanga mengantikan fungsi yang sebelumnya dilakukan oleh Badan Pengawas Pasar Modal (Bapepam) kepada Otoritas Jasa Keuangan (OJK) . Perbedaan pengawasan yang ada sebelumnya dengan Pengawasan di Bawah OJK adalah bahwa pengawasan di bawah OJK dilandasi semangat untuk memberikan perhatian kepada perlindungan dan edukasi bagi konsumen. Edukasi dan perlindungan konsumen keuangan diarahkan untuk meningkatkan kepercayaan dari investor dan konsumen dalam setiap aktivitas dan kegiatan usaha di sektor jasa keuangan dan memberikan peluang dan kesempatan untuk perkembangan sektor jasa keuangan secara adil, efisien, dan transparansi. Dalam jangka panjang, industri keuangan sendiri juga akan mendapat manfaat yang positif untuk memacu peningkatan efisiensi sebagai respon dari tuntutan pelayanan yang lebih prima terhadap pelayanan jasa keuangan.

\section{Daftar Pustaka}

Lastuti Abubakar, 2009, Transaksi Derifatif Di Indonesia, Books terrace\& Library, Bandung.

Irsan Nasarudin dkk, 2011, Aspek Hukum Pasar Modal Indonesia, Kencana Prenada Media Group, Jakarta.

Martalena. Maya Malinda, 2011, Pengantar Pasar Modal, Andi Publisher, Yogyakarta.

Pandji Anoraga. Piji Pakarti, 2008, Pengantar Pasar Modal, Rineka Cipta, Jakarta.

Rusdin, 2005, Pasar Modal, Alfabeta, Bandung.

Yusuf Anwar, 2008, Penegakan Hukum dan Pengawasan Pasar Modal Indonesia, Alumni, Bandung.

Artawan, Peranan Pasar Modal di Masa Mendatang, 2002, PT BEJ, Jakarta. 


\section{Peraturan Perundang-undangan}

Undang-Undang No. 8 Tahun 1995 Tentang Pasar Modal

Undang-Undang Nomor 21 Tahun 2011 tentang Otoritas Jasa Keuangan

\section{Website}

Tanpa Nama, "sejarah-dan-milestone" www.idx.co.id, tentang-bei sejarah-danmilestone, diakses 31 Mei 2019 pukul 10.47

Tanpa Nama, “FAQ-Otoritas-Jasa-Keuangan”, www.ojk.go.id, diakses 23 Mei 2019 pukul 10.47 